\title{
Correction to: The effect of different logging regimes on the ecomorphological structure of stream fish assemblages in the Brazilian Amazon
}

\author{
Laís L. Jacob • Bruno S. Prudente - Luciano F. A. Montag • Rogério R. Silva
}

Accepted: 7 June 2021 / Published online: 23 June 2021

(C) The Author(s), under exclusive licence to Springer Nature Switzerland AG 2021

Correction to: Hydrobiologia (2021)

848:1027-1039 https://doi.org/10.1007/s10750-02004508-3

The article The effect of different logging regimes on the ecomorphological structure of stream fish assemblages in the Brazilian Amazon, written by Laís L. Jacob, Bruno S. Prudente, Luciano F. A. Montag, Rogério R. Silva, was originally published online on 6 February 2021 with Open Access under a Creative Commons Attribution (CC BY) licence 4.0.

The original article can be found online at https:// doi.org/10.1007/s10750-020-04508-3.

\section{L. Jacob ( $\bowtie)$}

Museu Paraense Emílio Goeldi (MPEG), Coordenação de Zoologia, Av. Perimetral, 1901, Terra Firme, Belém, PA 66077-830, Brazil

e-mail: lais_lobato@hotmail.com

L. L. Jacob · L. F. A. Montag

Laboratory of Ecology and Conservation (LABECO), Instituto de Ciências Biológicas, Universidade Federal do Pará, Av. Bernardo Saião, Guamá, Belém,

PA 68625-150, Brazil

\section{B. S. Prudente}

Laboratory of Ecology and Conservation of the Amazon (LABECA), Universidade Federal Rural da Amazônia, Rua Professora Antônia Cunha de Oliveira, Vila Nova, Capitão Poço, PA 68650-000, Brazil
After publication in volume 848 , issue 5 , page 1027-1039 the author(s) decided to cancel the Open Access. Therefore, the copyright of the article has been changed on 6 June 2021 to (c) The Author(s), under exclusive licence to Springer Nature Switzerland AG 2021 with all rights reserved.

Publisher's Note Springer Nature remains neutral with regard to jurisdictional claims in published maps and institutional affiliations.

\section{R. R. Silva}

Museu Paraense Emílio Goeldi (MPEG), Coordenação de Ciências da Terra e Ecologia, Av. Perimetral, 1901, Terra Firme, Belém, PA 66077-830, Brazil 